\title{
Upaya Meningkatkan Kemampuan Membaca Dan Menulis dengan Menggunakan Media Flashcard di Kelas 1 SDN Kamunti Semester Ganjil Tahun Pelajaran 2018/2019
}

\author{
Nursani \\ SDN Kamunti \\ nursani_sdn1kamunti65@gmail.com
}

\begin{abstract}
Bahasa memiliki peran sentral dalam perkembangan intelektual, sosial, dan emosional peserta didik dan merupakan penunjang keberhasilan dalam mempelajari semua bidang studi. Pembelajaran bahasa diharapkan membantu peserta didik mengenal dirinya, budayanya, dan budaya orang lain, mengemukakan gagasan dan perasaan, berpartisipasi dalam masyarakat yang menggunakan bahasa tersebut, dan menemukan serta menggunakan kemampuan analitis dan imaginatif yang ada dalam dirinya. Penelitian ini bertujuan untuk mengetahui Upaya Meningkatkan Kemampuan Membaca dan Menulis dengan Menggunakan Media Flashcard di Kelas 1 SDN Kamunti Semester Ganjil Tahun Pelajaran 2018/2019. Jenis ini adalah Penelitian Tindakan Kelas (PTK), Desain Penelitian Tindakan Kelas yang digunakan sesuai dengan metode PTK Aqib. Setiap siklus meliputi perencanaan, tindakan, pengamatan, evaluasi serta refleksi. Subyek dalam penelitian ini adalah siswa SDN Kamunti Tahun Pelajaran 2018/2019 sebanyak 18 orang. Instrumen yang digunakan dalam penelitian ini adalah soal tes dan lembar observasi aktivitas siswa. Dari hasil penelitian dan pembahasan dapat di tarik kesimpulan bahwa ada peningkatkan Kemampuan Membaca dan Menulis dengan Menggunakan Media Flashcard di Kelas 1 SDN Kamunti Semester Ganjil Tahun Pelajaran 2018/2019, peningkatan kemampuan membaca dan menulis siswa sebesar 40,03\% kategori kurang baik pada siklus I. Pada siklus II persentase ketuntasan kemampuan membaca dan menulis $83,79 \%$ pada kategori sangat baik.
\end{abstract}

Keywords: Kemampuan membaca dan menulis, Media Flashcard.

\section{PENDAHULUAN}

Salah satu aspek perkembangan yang harus dikembangkan pada anak adalah aspek perkembangan bahasa. Bahasa merupakan kemampuan untuk berkomunikasi dengan orang lain (Syamsu Yusuf, 2007). Hal ini mencakup semua cara untuk berkomunikasi, menyebutkan pikiran, dan perasaan yang dinyatakan dalam bentuk lambang atau simbol untuk mengungkapkan suatu pengertian dengan menggunakan lisan, tulisan, isyarat, bilangan, lukisan, dan mimik muka.

Soetjiningsih (2012) menjelaskan bahwa kemampuan berbahasa merupakan indikator dari seluruh perkembangan anak. Hal tersebut dikarenakan kemampuan berbahasa sensitif terhadap keterlambatan atau kerusakan pada sistem lainnya yang melibatkan berbagai kemampuan

Bahasa memiliki peran sentral dalam perkembangan intelektual, sosial, dan emosional peserta didik dan merupakan penunjang keberhasilan dalam mempelajari semua bidang studi. Pembelajaran bahasa diharapkan membantu peserta didik mengenal dirinya, budayanya, dan budaya orang lain, mengemukakan gagasan dan perasaan, berpartisipasi dalam masyarakat yang menggunakan bahasa tersebut, dan menemukan serta menggunakan kemampuan analitis dan imaginatif yang ada dalam dirinya.

Disamping itu pembelajaran Bahasa Indonesia diarahkan untuk meningkatkan kemampuan peserta didik untuk berkomunikasi dalam Bahasa Indonesia dengan baik dan benar, baik secara lisan maupun tulis, serta menumbuhkan apresiasi terhadap hasil karya pendidikan bangsa.

Secara umum membaca dan menulis huruf latin atau ejaan Bahasa Indonesia juga praktek empirik pengajaran di lembaga pendidikan formal maupun non formal, 
seperti SD dan TK, membaca dan menulis untuk kategori pemula bukan ekspresif merupakan mata pelajaran yang tidak bisa dipisahkan atau sudah menjadi keharusan anak menerimanya. Kalau mengambil perumpamaan makanan, adalah kebutuhan pokok sehari-hari.

Namun kemampuan membaca dan menulis menjadi sesuatu yang sangat sulit bagi siswa, terutama siswa kelas 1 SDN Kamunti. Evaluasi pembelajaran menulis yang dilaksanakan hanya $38,89 \%$ siswa mendapat nilai lebih dari 73 dari jumlah siswa sebanyak 18 siswa. Kekurang terampilan siswa membaca dan menulis deskripsi terletak pada (1) cara melafalkan huruf yang tidak jelas dan runtut, (2) membaca suku kata, (3) tulisannya yang masih banyak kesalahan.

Berdasarkan pengamatan yang dilakukan oleh peneliti ternyata peserta didik banyak yang kurang semangat seperti banyak yang bicara sendiri, ngantuk dan kurang antusias dalam bertanya. Beberapa asumsi kurang minatnya peserta didik pada pelajaran tersebut dikarenakan guru yang mengajarkan kurang variatif dalam menerapkan model pembelajaran.

Untuk menarik peserta didik supaya berminat dalam pembelajaran menulis maka sebagai guru kelas wajib mencari solusi yang tepat untuk mengatasi kesulitan-kesulitan di atas, salah satunya dengan mencari metode pembelajaran yang efektif, untuk meningkatkan motivasi siswa dalam meningkatkan kemampuannya membaca dan menulis.

Memahami tentang pentingnya membaca sejak dini, perlunya penggunaan cara dan strategi yang tepat dalam pembelajaran membaca pada anak usia dini. Menurut Nurbiana Dhieni dkk., (2008), strategi yang dapat digunakan adalah dengan pendekatan pengalaman berbahasa. Pendekatan ini dilaksanakan melalui bermain, melibatkan anak dalam berbagai kegiatan baik kegiatan yang bersifat individual, kelompok kecil, maupun kelompok besar. Selain itu, motivasi dan minat yang sesuai dengan anak perlu diperhatikan agar pembelajaran dapat diterima anak dengan baik.
Salah satu media pembelajaran yang penuh dengan permainan yang mengarah pada keaktifan siswa yang bisa dilakukan guru Bahasa Indonesia adalah penggunaan media flashcard. Flashcard adalah media yang sederhana namun sangat bermanfaat untuk menampilkan dan melatih kosa kata. Media flashcard dapat berupa kartu bergambar yang dibawahnya terdapat tulisan yang di desain dengan warna yang menarik sehingga hal ini akan menyenangkan anak, maka anak akan termotivasi untuk belajar.

Dina Indriana (2011) juga menyebutkan bahwa flash card adalah media pembelajaran dalam bentuk kartu bergambar dengan ukuran sekitar $25 \mathrm{~cm} \quad x \quad 30 \mathrm{~cm}$. Gambar yang ditampilkan berupa gambar tangan, foto, atau gambar yang sudah ada ditempelkan pada lembaran kartu-kartu tersebut. Kelebihan flash card ini adalah bersifat portabel, praktis dalam pembuatan dan penggunaannya, mudah diingat karena gambar yang ada berwarna sehingga menarik perhatian, dan menyenangkan.

Kegiatan pembelajaran dengan media flash card yang menarik dapat memberikan stimulasi pada anak untuk mengembangkan kemampuan membaca permulaan. Berdasarkan latar belakang di atas, peneliti tertarik melakukan penelitian tindakan kelas dengan judul "Upaya Meningkatkan Kemampuan Membaca Dan Menulis dengan Menggunakan Media Flashcard di Kelas 1 SDN Kamunti Semester Ganjil Tahun Pelajaran 2018/2019”.

\section{METODE \\ Jenis Penelitian}

Jenis penelitian yang digunakan dalam penelitian ini adalah penelitian tindakan kelas (classroom action research). Menurut Wina Sanjaya (2009) penelitian tindakan kelas adalah proses pengkajian masalah pembelajaran di dalam kelas melalui refleksi diri dalam upaya untuk memecahkan masalah tersebut dengan cara melakukan berbagai tindakan yang terencana dalam situasi nyata serta menganalisis setiap pengaruh dari perlakuan tersebut. Rincian kegiatan pada setiap 
tahapan yaitu 1) perencanaan tindakan, 2) pelaksanaan tindakan, 3) pengamatan atau observasi 4) refleksi (Azmin 2019). Apabila siklus I tidak memenuhi ketuntasan klasikal, maka akan dilanjutkan ke siklus II, dan seterusnya. Desain penelitian tindakan kelas sebagai berikut:

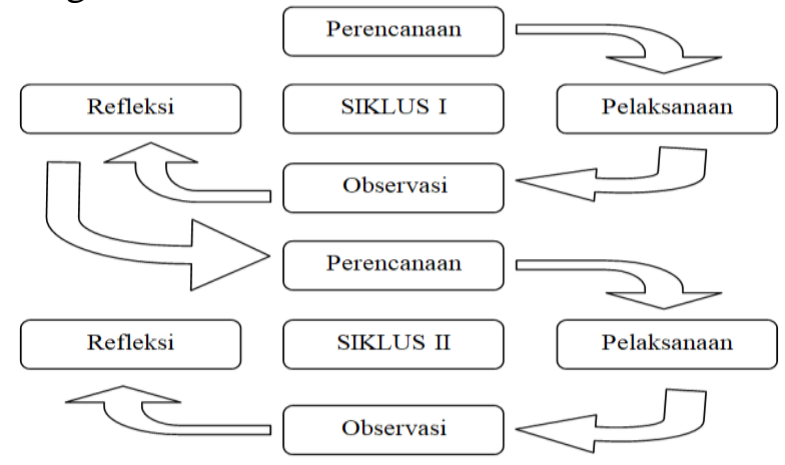

Gambar 1. Siklus dalam Penelitian Tindakan Kelas (Aqib, 2007).

\section{Waktu dan Tempat Penelitian}

Penelitian ini dilaksanakan di SDN 1 Kamunti, pada Semester Ganjil Tahun Pelajaran 2018/2019.

\section{Subyek Penelitian}

Subyek dalam penelitian ini adalah siswa kelas I SDN kamunti yang berjumlah 18 orang yang masih aktif pada semester ganjil Tahun Pelajaran 2018/2019.

\section{Prosedur Penelitian} berikut :

Tahapan dalam penelitian ini sebagai Siklus I

a. Tahap perencanaan

Peneliti menentukan titik-titik atau fokus masalah yang perlu mendapatkan perhatian khusus kemudian mencari alternatif tindakan untuk mengatasi permasalahan tersebut. Pada tahap ini peneliti menjelaskan tentang apa, mengapa, kapan, di mana, oleh siapa, dan bagaimana tindakan tersebut dilakukan.

1) Menyusun RPP

2) Menyiapkan media flash card yang sesuai dengan tema.

3) Menyiapkan instrumen pengamatan dalam bentuk panduan observasi untuk mengungkap kemampuan membaca pemulaan yang dapat di uraikan dalam berbagai kemampuan yaitu kemampuan menyebutkan kelompok gambar yang memiliki bunyi atau huruf awal yang sama dan membaca gabungan suku kata dalam sebuah kata sederhana yang terdiri dari 2 suku kata.

b. Tahap pelaksanaan tindakan

Tahap tindakan ini merupakan implementasi atau penerapan isi rancangan yang berupa mengenakan tindakan di kelas. Peneliti dan guru melaksanakan tindakan yang telah disusun sebelumnya pada proses pembelajaran. Pada tahap ini, guru melaksanakan pembelajaran sesuai dengan tema dan RPP.

Pelaksanaan tahap ini dilakukan bersamaan dengan berlangsungnya tindakan yang memuat kegiatan pembelajaran menggunakan media flash card untuk meningkatkan kemampuan membaca permulaan anak.

c. Refleksi

Tahap refleksi yang dilakukan adalah n mengulas secara kritis tentang perubahan yang terjadi pada siswa, guru, dan suasana kelas. Berdasarkan hasil reflsksi ini, peneliti dapat melakukan revisi terhadap rencana kegiatan selanjutnya atau terhadap rencana siklus II. Pada tahap ini, peneliti menganalisis tes siklus I. Dari hasil tersebut nantinya akan dibandingkan dengan hasil tes siklus II.

\section{Siklus II}

Tahapan siklus II sama dengan siklus I, Siklus II di lakukan apabila pelajaran pada siklus I belum berhasil mencapai ketuntasan atau hasil belajar dan proses mengajar belum sesuai dengan apa yang diinginkan.

\section{Instrumen Penelitian}

Instrumen Instrument yang digunakan dalam penelitian ini terdiri dari:

1. Tes Kemampuan Membaca dan Menulis

Tes dilakukan oleh peneliti untuk mengumpulkan data hasil belajar siswa pada akhir siklus. Tes digunakan untuk mengetahui kemampuan memabaca dan 
menulis siswa setelah dilakukan pembelajaran dengan Media Flashcard.

2. Lembar Observasi

Dalam penelitian ini, obervasi yang dilakukan peneliti untuk mengumpulkan informasi tentang perilaku anak sebagai pengaruh dari tindakan yang dilakukan dalam meningkatkan kemampuan membaca dan menulis.

\section{Teknik Analisis Data}

Data yang diperoleh selanjutnya dianalisis dengan menggunakan statistik deskriptif. Hasil yang diperoleh kemudian dimasukkan dalam lima kategori predikat yang dapat dilihat pada tabel 1 sebagai berikut (Arikunto, 2010).

Tabel 1. Kategori Peringkat Menulis dan membaca

\begin{tabular}{|r|c|c|}
\hline No. & Interval & Kategori \\
\hline 1. & $81 \%-100 \%$ & Sangat baik \\
\hline 2. & $61 \%-80 \%$ & Baik \\
\hline 3. & $41 \%-60 \%$ & Cukup \\
\hline 4. & $21 \%-40 \%$ & Kurang baik \\
\hline 5. & $0 \%-20 \%$ & Tidak baik \\
\hline
\end{tabular}

Keberhasilan penelitian tindakan kelas ditandai dengan adanya perubahan menuju ke arah perbaikan. Keberhasilan hasil diperoleh jika terjadi peningkatan kemampuan membaca permulaan sesudah diberikan tindakan.

Indikator keberhasilan dalam penelitian ini adalah meningkatnya kemampuan membaca permulaan yang dapat dilihat dari proses pembelajaran dengan menggunakan media flash card. Peneliti menentukan indikator keberhasilan yaitu dengan persentase rata-rata $\geq 80 \%$ dengan kriteria sangat baik.

\section{HASIL DAN PEMBAHASAN \\ Hasil Penelitian \\ Kondisi Awal Siswa}

Kondisi awal siswa yaitu saat siswa belum menerima pembelajaran dengan media flashcard. Sebelum dilakukan penelitian tindakan kelas ini pembelajaran masih menggunakan metode pembelajaran yang kurang inovatif, yaitu pembelajaran masih berpusat pada guru sehingga aktivitas belajar siswa masih kurang optimal. Selain itu guru juga masih menggunakan media pendukung berupa buku paket dalam menyampaikan materi sehingga kemampuan membaca dan menulis siswa kurang optimal. Hal ini terlihat dari kemampuan membaca dan menulis siswa yang masih rendah yaitu sebesar $55 \%$. Penelitian tindakan kelas ini menggunakan media flashcard diharapkan dapat meningkatkan kemampuan membaca dan menulis siswa

\section{Hasil Siklus I}

a) Perencanaan

Pada tahap perencanaan ini peneliti menyiapkan:

1. Rencana Pelaksanaan Pembelajaran

2. Menyediakan media flashcard

3. Menyiapkan lembar observasi

b) Pelaksanaan Tindakan

Pelaksanaan kegiatan belajar mengajar untuk siklus I dilaksanakan di kelas I dengan jumlah siswa 18 siswa. Proses pembelajaran ini dimulai dengan mengucapkan salam dan mengajak siswa untuk berdoa bersama-sama, apersepsi dan memberikan acuan, memotivasi siswa untuk mengikuti pembelajaran dengan baik demi tercapainya tujuan yang diharapkan dan dilanjutkan dengan mengabsen siswa, Selanjutnya guru menerangkan materi tentang membaca dan menulis tentang tema benda disekitarku.

Saat kegiatan membaca bersama, terlihat beberapa siswa tidak ikut membaca. Siswa bermain dan santai meletakkan kepalanya di atas meja. Pada saat kegiatan ini terlihat adanya keberanian siswa untuk mengungkapkan ide/pikiran yang pada akhirnya nanti dapat dituangkan dalam bentuk tulisan. Selanjutnya guru membuat proses belajar yang aktif, dan terlihat siswa sangat antusias pada saat melaksanakan kegiatan ini, sehingga tumbuh rasa percaya diri siswa. Setelah kartu-kartu tersusun dengan baik dan menjadi bermakna, guru meminta siswa secara bergilir untuk membaca huruf-huruf pada kartu sesuai yang ditunjukkan oleh guru dan siswa lain mengomentari. Kegiatan selanjutnya adalah guru membagikan kartu 
(flashcard menulis) untuk masing-masing siswa. Guru meminta siswa untuk mengamati kartu tersebut. Selanjutnya, untuk mengetahui daya serap siswa dalam pembelajaran guru mengevaluasi dengan menyuruh siswa maju ke depan untuk membaca dan memberikan lembaran tes tertulis kepada siswa untuk dikerjakan secara individual. Pada akhir pembelajaran guru bersama siswa mengakhiri dan menutup kegiatan dengan berdoa bersama dilanjutkan salam.

c) Pengamatan

Berikut adalah hasil pengamatan siklus I

Tabel 2. Hasil Evaluasi Kemampuan Membaca dan menulis Siklus I

\begin{tabular}{|c|c|c|c|c|c|}
\hline $\begin{array}{c}\text { Aaspek } \\
\text { Perkembangan }\end{array}$ & Indikator & $\begin{array}{c}\text { Skor } \\
\text { Keseluruhan }\end{array}$ & $\begin{array}{l}\text { Persentase } \\
(\%)\end{array}$ & $\begin{array}{l}\text { Rata-rata } \\
\text { Persentase } \\
(\%)\end{array}$ & Kriteria \\
\hline \multirow[t]{2}{*}{$\begin{array}{l}\text { Menyebutkan } \\
\text { kelompok gambar } \\
\text { yang memiliki bunyi } \\
\text { atau hurufawal yang } \\
\text { sama }\end{array}$} & $\begin{array}{l}\text { Menunjukkan media } \\
\text { yang mempunyai } \\
\text { huruf awal yang } \\
\text { sama dengan yang } \\
\text { ditunjulkkan guru }\end{array}$ & 48 & $43,51 \%$ & \multirow{3}{*}{$40,03 \%$} & \multirow{3}{*}{$\begin{array}{c}\text { Kurang } \\
\text { Baik }\end{array}$} \\
\hline & $\begin{array}{l}\text { Menunjukkan media } \\
\text { yang mempunyai } \\
\text { bunyi awal (suku } \\
\text { kata awal) yang } \\
\text { sama dengan yang } \\
\text { ditunjukkan guru }\end{array}$ & 43 & $38,88 \%$ & & \\
\hline $\begin{array}{lr}\text { Membaca } & \text { gabungan } \\
\text { suku kata } & \text { dalam } \\
\text { sebuah } & \text { kata } \\
\text { sederhana } & \text { yang } \\
\text { terdiri dari } 2 & \text { sulku } \\
\text { kata } & \end{array}$ & 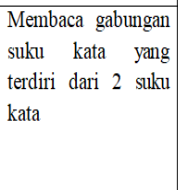 & 37 & $33,33 \%$ & & \\
\hline
\end{tabular}

Berdasarkan tabel 2 di atas, dapat diketahui bahwa hasil dari kegiatan Pratindakan kemampuan masih kurang baik (40,03), Hal ini dapat dilihat dari data kemampuan membaca, yaitu pertama, kemampuan anak dalam menunjukkan media yang mempunyai huruf awal yang sama seperti media yang ditunjukkan guru memperoleh persentase sebesar $43,51 \%$. Kedua, kemampuan anak dalam menunjukkan media yang mempunyai suku kata awal yang sama seperti media yang ditunjukkan guru memperoleh persentasi sebesar 38,88\%. Ketiga, kemampuan anak dalam membaca gabungan suku kata memperoleh persentase 33,33\%.

d) Refleksi

Berdasarkan hasil pengamatan pada siklus I baik guru kemampuan membaca dan menulis anak masih dalam kategori kurang baik (40,03), Siswa masih kurang aktif dalam proses pembelajaran dengan media flashcard.

\section{Hasil Siklus II}

Melihat hasil siklus I yang kurang maksimal dalam pembelajaran maka guna memaksimalkan hasil yang diingin dicapai maka dilakukan siklus lanjutan. Siklus lanjutan ini juga terdiri dari tindakan perencanaan, pelaksanaan tindakan, observasi dan refleksi.

\section{a) Perencanaan}

Perencanaan tindakan pada siklus II ini dilakukan tidak jauh beda dengan siklus I yaitu dengan membuat Rencana Pembelajaran (RP), Menyiapkan media flashcard, dan menyiapkan lembar observasi

b) Pelaksanaan

Pelaksanaan kegiatan belajar mengajar untuk siklus II dilaksanakan di kelas I dengan jumlah siswa 18 siswa. Proses pembelajaran tidak jauh berbeda dengan yang dilakukan pada siklus I, hanya saja lebih diintensifkan pembelajarannya. Pembelajaran dimulai guru mengucapkan salam dan mengajak siswa untuk berdoa bersama-sama, apersepsi dan dilanjutkan dengan memantau kehadiran siswa. Selanjutnya guru menerangkan materi tentang benda disekitarku.

Kegiatan selanjutnya adalah guru mendekati siswa satu per satu, memerintahkan siswa membaca kata yang terdapat pada gambar flash card,. Guru meminta siswa mengamati kartu tersebut dan juga meminta siswa untuk menyalin tulisan yang ada pada kartu ke dalam buku milik siswa. Hal ini dilakukan dalam rangka pengamatan kemampuan membaca siswa serta pengamatan proses menulis siswa. Kartu-kartu (media flashcard) baik flashcard membaca maupun flashcard menulis didesain dengan dilengkapi gambar-gambar yang menarik perhatian siswa dan disesuaikan dengan materi yang sedang dipelajari, sehingga siswa merasa senang dan membawa dampak baik pada keikutsertaan siswa untuk aktif dalam kegiatan pembelajaran. Pada siklus II flashcard didesain dengan cetakan print berwarna sehingga guru memberi kesempatan kepada siswa yang cepat dan 
selesai lebih awal dalam menulis untuk mewarnai flashcard tersebut.

Selanjutnya, untuk mengetahui kemampuan daya serap siswa dalam pembelajaran guru memberikan lembaran tes tertulis kepada siswa untuk dikerjakan secara individu untuk membaca dan menyalin menjadi tulisan dengan maju kedepan. Pada akhir pembelajaran guru bersama siswa mengakhiri dan menutup kegiatan dengan berdoa bersama.

c) Pengamatan

Hasil pengamatan siklus II dicatat dalam lembar observasi yang telah dipersiapkan. Pengamatan siklus II diperoleh hasil $83,79 \%$ siswa aktif dalam pembelajaran dengan menggunakan media flashcard.

Tabel 3. Hasil Evaluasi Kemampuan Membaca dan menulis Siklus II

\begin{tabular}{|c|c|c|c|c|c|}
\hline $\begin{array}{c}\text { Aaspek } \\
\text { Perkembangan }\end{array}$ & Indikator & $\begin{array}{c}\text { Skor } \\
\text { Keseluruhan }\end{array}$ & $\begin{array}{c}\text { Persentase } \\
(\%)\end{array}$ & $\begin{array}{c}\text { Rata-rata } \\
\text { Persentase } \\
(\%)\end{array}$ & Kriteria \\
\hline \multirow[t]{2}{*}{$\begin{array}{l}\text { Menyebutkan } \\
\text { kelompok gambar } \\
\text { yang memiliki bunyi } \\
\text { atau hurufawal yang } \\
\text { sama }\end{array}$} & $\begin{array}{l}\text { Menunjukkan media } \\
\text { yang mempunyai } \\
\text { hunuf awal yang } \\
\text { sama dengan yang } \\
\text { ditunjukkan guru }\end{array}$ & 85 & $81,79 \%$ & \multirow{3}{*}{$83,79 \%$} & \multirow{3}{*}{ Sangat Baik } \\
\hline & $\begin{array}{l}\text { Menunjukkan media } \\
\text { yang mempunyai } \\
\text { bunyi awal (suku } \\
\text { kata awal) yang } \\
\text { sama dengan yang } \\
\text { ditunjukkan guru }\end{array}$ & 83 & $82,08 \%$ & & \\
\hline \begin{tabular}{lr}
\multicolumn{2}{l}{ Membaca gabungan } \\
suku kata & dalam \\
sebuah & kata \\
sederhana & yang \\
terdiri dari & 2 suku \\
kata &
\end{tabular} & \begin{tabular}{lll}
\multicolumn{3}{l}{ Membaca gabungan } \\
suku kata & yang \\
terdiri dari 2 & suku \\
kata & &
\end{tabular} & 81 & $82,16 \%$ & & \\
\hline
\end{tabular}

d) Refleksi

Berdasarkan tabel 3 di atas, dapat diketahui bahwa hasil dari kegiatan Pratindakan kemampuan masih sangat baik $(83,79)$, Hal ini dapat dilihat dari data kemampuan membaca, yaitu pertama, kemampuan anak dalam menunjukkan media yang mempunyai huruf awal yang sama seperti media yang ditunjukkan guru memperoleh persentase sebesar 81,79\%. Kedua, kemampuan anak dalam menunjukkan media yang mempunyai suku kata awal yang sama seperti media yang ditunjukkan guru memperoleh persentasi sebesar 82,08\% Ketiga, kemampuan anak dalam membaca gabungan suku kata memperoleh persentase $82,16 \%$. Hal ini menunjukkan siswa sudah mulai aktif dan maksimal dalam pembelajaran, Siswa semaki baik dalam membaca dan menulis

Hasil evaluasi pembelajaran pembelajaran pada siklus II dengan media flashcard mengalami peningkatan sebesar $83,79 \%$ pada kategori sangat baik. Hasil tersebut menunjukkan bahwa pada siklus II ini secara klasikal siswa sudah tuntas.

\section{Pembahasan}

Berdasarkan tes kemampuan membaca dan menulisyang dilakukan tiap pembelajaran atau persiklusnya diketahui bahwa siswa semakin aktif pada pertemuan berikutnya meskipun pada pertemuan pertama hasilnya kurang dari harapan. Hal ini ditandai dengan semakin meningkatnya jumlah ketuntasan. Pada siklus I persentase kemampuan membaca dan menulis siswa sebesar 40,03\% kategori kurang baik. Pada siklus II persentase ketuntasan kemampuan membaca 83,79\% pada kategori sangat baik..

Peningkatan kemampuan membaca dan menulis merupakan tolak ukur untuk mengetahui tingkat keberhasilan siswa dalam proses belajar mengajar. Proses belajar mengajar dikatakan baik, bila proses tersebut dapat membangkitkan kegiatan belajar yang efektif. Jika dilihat dari kemampuan membaca dan menulisyang diperoleh siswa persiklus mengalami peningkatan. Peningkatan kemampuan membaca dan menulis dikarenakan adanya peningkatan aktivitas guru dan siswa pada siklus I dan II, artinya proses pembelajaran dengan media flashcardmengalami perbaikan.

\section{KESIMPULAN}

Dari hasil penelitian dan pembahasan dapat di tarik kesimpulan bahwa ada peningkatkan Kemampuan Membaca dan Menulis dengan Menggunakan Media Flashcard di Kelas 1 SDN Kamunti Semester Ganjil Tahun Pelajaran 2018/2019, peningkatan kemampuan membaca dan menulis siswa sebesar 40,03\% kategori kurang baik pada siklus I. Pada siklus II persentase ketuntasan kemampuan membaca dan menulis $83,79 \%$ pada kategori sangat baik. 


\section{DAFTAR PUSTAKA}

Arikunto. S. 2010. Prosedur Penelitian Suatu Pendekatan Praktek. Jakarta: Rineka Cipta.

Azmin, N., \& Nasir, M. (2019). PENERAPAN MODEL PEMBELAJARAN 5E UNTUK MENINGKATKAN

KETERAMPILAN PROSES SAINS DAN SIKAP ILMIAH SISWA KELAS VIII SMP NEGRI 6 KOTA BIMA. ORYZA Jurnal Pendidikan Biologi, 8(2), 40-46.

Aqib, 2007, Penelitian tindakan kelas. Bandung : CV Yrama Widya

Dina Indriana. (2011). Ragam Alat Bantu Media Pengajaran. Yogyakarta: Diva Press.

Nurbiana Dhieni, Lara Fridani, Gusti Yarmi, \& Nany Kusniaty. (2008). Metode Pengembangan Bahasa. Jakarta: Universitas Terbuka.

Syamsu Yusuf (2007). Psikologi Perkembangan Anak \& Remaja. Bandung. Remaja Rosdakarya.

Wina Sanjaya. 2009. Penelitian Tindakan Kelas. Jakarta : Kencana. Yoni, Acep. 2010. Menyusun Penelitian Tindakan Kelas. Yogyakarta 